\title{
KVALITETA SURADNJE UČITELJA I POMOĆNIKA U NASTAVI IZ PERSPEKTIVE UČITELJA I POMOĆNIKA
}

\author{
Mateja Marinić \\ Osnvna škola Luka, Sesvete, Republika Hrvatska \\ Klara Matejčić \\ Centar inkluzivne potpore IDEM, Zagreb, Republika Hrvatska \\ Ljiljana Igrić \\ Učilište za obrazovanje odraslih IDEM, Zagreb, Republika Hrvatska
}

\begin{abstract}
Sažetak
Da bi razred bio podržavajuća zajednica u procesu učenja, ona zahtijeva kvalitetnu suradnju učitelja i pomoćnika u nastavi. Brojna istraživanja ukazuju na pozitivne učinke suradnje učitelja i pomoćnika u nastavi unutar redovnog sustava odgoja i obrazovanja. Posebice se naglašava da oni učitelji koji unutar razreda imaju podršku pomoćnika u nastavi osjećaju veće zadovoljstvo u svakodnevnom radu za razliku od onih kod kojih takav oblik podrške izostaje. U predstavljenom se istraživanju na temelju istraživačkih pitanja nastoji dobiti uvid u percepciju učitelja i pomoćnika o načinima njihove suradnje. Također, želi se doznati koji čimbenici doprinose kvaliteti suradnje. Provedeno je istraživanje obuhvatilo učitelje razredne i predmetne nastave $(N=40)$ te pomoćnike u nastavi $(N=29)$ iz sedam osnovnih škola na području Republike Hrvatske. Podaci su prikupljeni fokus grupnim intervjuima te analizirani i obrađeni metodom kvalitativne analize podataka. Rezultati upućuju na specifična područja suradnje učitelja i pomoćnika u nastavi. S obzirom na to da su pomoćnici ti koji najviše vremena provode u neposrednom radu s učenikom, učitelji u njima vide suradnika koji dobro poznaje učenika, njegove sposobnosti i karakteristike. Stoga, na temelju provedenog istraživanja možemo zaključiti kako pomoćnik u nastavi ima neizostavnu ulogu u edukacijskom uključivanju učenika s posebnim odgojno-obrazovnim potrebama.
\end{abstract}

Ključne riječi: inkluzivno obrazovanje, učitelj, pomoćnik u nastavi, suradničko poučavanje, kvalitativno istraživanje

\section{UvoD}

Edukacijska inkluzija, koja podrazumijeva uključivanje sve djece u redovan sustav odgoja i obrazovanja, u Republici Hrvatskoj i dalje nailazi na mnogobrojne izazove. Učitelji kao odgojno-obrazovni djelatniciimaju značajnu ulogu u procesu ostvarivanja inkluzije. Oni se još uvijek nalaze pred izazovom prihvaćanja učenika s posebnim edukacijskim potrebama te pronalaženja odgovarajućih metoda poučavanja (Igrić, Cvitković, Wagner Jakab, 2009). Ono što edukacijska inkluzija pretpostavlja, jest promjena uloge odgojno-obrazovnih djelatnika koja je u Republici Hrvatskoj iznimno potrebna, a učitelji kao kreatori i nositelji nastavnog procesa jedni su od njih. Njihova je odgovornost implementirati najbolje standarde poučavanja i zadovoljiti potrebe svakog učenika u učionici. Ako se u razredu nalazi nekoliko učenika koji iskazuju specifične potrebe, odnosno prilagodbu nastavnog sadržaja i procesa, ta je odgovornost još veća.

U hrvatskim školama pomoćnici u nastavi već godinama pružaju podršku brojnim učenicima s posebnim edukacijskim potrebama pri usvajanju nastavnog gradiva i izvršavanju sva- 
kodnevnih aktivnosti. Osim pružanja podrške u obrazovnom dijelu, oni svakodnevno obavljaju i u druge zadatke, primjerice: surađuju s učiteljima, roditeljima i stručnim suradnicima te ravnateljem škole. Osim s učenikom pomoćnici su najčešće u neposrednom kontaktu s učiteljima, bilo razredne bilo predmetne nastave, te s njima blisko surađuju.

\section{Suradničko poučavanje}

Suradničko poučavanje sve više pronalazi svoje mjesto u učionicama s ciljem uspješnog načina zadovoljenja odgojno-obrazovnih potreba svih učenika (Grant, 2014). Uspješno suradničko poučavanje događa se onda kada dvoje ili više odgojno-obrazovnih djelatnika zajedno poučavaju raznoliku grupu učenika unutar jednog zajedničkog prostora (NJEA, 2012). Glavna premisa koja stoji iza spomenutog modela poučavanja jest da svi učenici bez obzira na svoje potrebe imaju pravo sudjelovanja u školskom kurikulumu do najveće moguće razine (Sharpe i Hawes, 2003). Grant (2014) navodi da oni učenici koji iskazuju posebne edukacijske potrebe kod usvajanja potrebnih vještina i nastavnog gradiva nisu smješteni u posebne uvjete. Spomenuti se učenici nalaze u svojoj grupi vršnjaka uredovnoj učionici gdje se ostvaruje proces učenja i podučavanja.

Da bi se suradničko poučavanje kao takvo ostvarilo, potrebna je prije svega spremnost učitelja na suradnju kao i dovoljna opremljenost škole, odnosno pristupačnost resursa u vidu pomoćnika u nastavi (Vaughn i Schumm, 1995). Arguelles i sur. (2000) navode nekoliko sastavnica učinkovitog suradničkog poučavanja, a to su: zajedničko planiranje, fleksibilnost, dijeljenje rizika, definiranje uloga i odgovornosti, kompatibilnost, edukacijske vještine i administrativna potpora.

\section{Pristupi suradničkom poučavanju}

Mnogo je načina na koji učitelji mogu pristupiti suradnji s pomoćnikom u nastavi. Onaj najčešći jest da učitelj dodjeljuje odgovornost pomoćniku koja se odnosi na jednog ili dvoje učenika s posebnim edukacijskim potrebama, no postoje i drugi načini koji se temelje na specifičnim metodama.

Nacionalni je centar za edukacijsko restrukturiranje i inkluziju (SAD) 1995. godine ispitivao iskustva učitelja koji su radili s učenicima s teškoćama. Prema dobivenim rezultatima utvrđena su četiri glavna pristupa suradničkom poučavanju: suportivni, paralelni, komplementarni i timski (Nacionalni centar za edukacijsko restrukturiranje i inkluziju, 1995 prema Igrić, 2015).

a) U suportivnom pristupu učitelj ima vodeću ulogu u poučavanju, a druga osoba (pomoćnik u nastavi) pruža potporu učenicima u razredu, prati rad učenika te pruža pojedinačnu potporu. Učitelj je taj koji usmjerava tijek poučavanja (Villa i sur., 2004, prema Igrić, 2015).

b) Paralelni pristup podrazumijeva istodobno podučavanje različite grupe učenika u različitim dijelovima učionice. $U$ takvom je pristupu dopušteno izmjenjivanje u radu s pojedinom grupom, a ponekad jedna grupa učenika može raditi i samostalno (Villa i sur., 2004, prema Igrić, 2015).

c) Komplementarni pristup poučavanju u samom izvođenju nastave podrazumijeva pružanje suradnikove (pomoćnik u nastavi) podrške učitelju. Primjerice, pomoćnik može zapisivati bitne dijelove predavanja na ploču, sa skupinom učenika prije nastave uvježbava vještine koje će im trebati tijekom nastave, a za vrijeme nastave promatra kako se učenici koriste naučenim (Villa i sur., 2004, prema Igrić, 2015).

Nadalje, Vincentt, Cremin i Thomas (2005) identificirali su tri modela koji unaprjeđuju suradničko poučavanje odnosno suradnju učitelja i pomoćnika u nastavi. Prvi model ističe tzv. upravljanje učionicom (engl. Room Management) u kojem su uloge djelatnika jasno postavljene i definirane unutar učionice. $U$ navedenom modelu osoba zadužena za poučavanje (učitelj) 
Mateja Marinić, Klara Matejčić, Ljiljana Igrić KVALITETA SURADNJE UČITELA I POMOĆNIKA U NASTAVI IZ.

kraće vremensko razdoblje usmjerava pozornost na pojedinog učenika koji ima specifične potrebe u učenju radi identificiranja poteškoća te pružanja kvalitetne i stručne podrške. Za to vrijeme osoba zadužena za aktivnost (pomoćnik u nastavi) radi s ostatkom razreda. $U$ tom su slučaju učenici najčešće grupirani te im je dodijeljen određeni zadatak iz nastavnog plana koji je podučavan, ali ne i u potpunosti usvojen.

Drugimodel zona (engl. The Zoning Model) odnosi se na organizaciju učionice prema specifičnim područjima - zonama. Osobe zadužene za podučavanje nalaze se u pojedinoj zoni unutar koje su grupe učenika podijeljene prema dobivenim zadacima. Nakon što učenici završe s aktivnošću, prelaze u sljedeću zonu i započinju novu aktivnost.

Glavni cilj modela upravljanja učionicom i modela zona jest poticanje timskog rada, odnosno suradnje učitelja i pomoćnika kroz jasne uloge. Na takav način oni osiguravaju da je svaki član tima upoznat s time što je dužan raditi s učenicima i gdje se aktivnost odvija. Osim što potiče timski rad učitelja i pomoćnika, on također nastoji povećati razinu aktivnosti učenika dinamikom aktivnosti.

Treći model je model reflektivnog timskog rada (engl. The Reflective Teamwork Model) čiji je cilj unaprijediti timski rad i suradnju učitelja i pomoćnika redovitim susretima. Tako rade na vještinama komunikacije, planiranja i evaluacije provedenih aktivnosti. Također, identificiraju specifična područja koja su se iskazala uspješnima, ali i ona koja smatraju da bi trebali unaprijediti. Dobivene zaključke primjenjuju već u sljedećoj nastavnoj aktivnosti.

Predstavljeni teorijski koncepti služe kao primjer unaprjeđenja svakodnevne prakse suradnje učitelja i pomoćnika u nastavi. Oni pozivaju na primjenu dinamičnog rada s učenicima, mijenjaju ulogu učitelja koji ima kontinuiranu podršku još jednog odgojno-obrazovnog djelatnika. Od frontalnog načina rada prelazi se na grupni i individualni. Učitelj je sa svojom kompetentnošću u podučavanju usmjeren prema učenicima koji iskazuju specifične potrebe i/ili poteškoće prilikom usvajanja nastavnog gradiva, dok je pomoćnik zadužen za provođenje grupne aktivnosti s onim učenicima koji su već upoznati s nastavnim gradivom i zahtijevaju dobro utvrđivanje sadržaja vježbom ili ponavljanjem. Kao poželjan oblik suradnje možemo istaknuti model upravljanja učionicom koji se može kombinirati sparalelnim pristupom poučavanju, a on podrazumijeva veću aktivnost pomoćnika tijekom sata. No, važno je imati na umu da učitelj samostalno odredi njemu najpoželjniji model suradnje ovisno o sastavu razreda, odgojno-obrazovnim potrebama učenika, nastavnom sadržaju i vrsti nastavnog sata. Osim navedenog, potrebno je imati na umu važnost refleksije učitelja i pomoćnika na njihov rad zbog čega je nužno u središte pozornosti staviti i model reflektivnog timskog rada.

\section{Metoda}

Cilj je provedenog istraživanja koje je dio jednogodišnjeg projekta Centra inkluzivne potpore IDEM i Učilišta za obrazovanje odraslih IDEM - „Uloga pomoćnika u nastavi iz perspektive nastavnika i pomoćnika u nastavi“ - upoznati se sa suradnjom učitelja i pomoćnika. Želi se utvrditi koliko su spremni surađivati u okviru svakodnevnog rada te koliko su tom suradnjom zadovoljni. Njihove perspektive nastojimo sagledati kroz prizmu inkluzivnog pristupa odgoju i obrazovanju odnosno suradničkog poučavanja. Sukladno postavljenom cilju oblikovana su dva istraživačka pitanja:

1. istraživačko pitanje: Kakva je perspektiva pomoćnika i učitelja (razredne i predmetne nastave) o načinima njihove suradnje?

2. istraživačko pitanje: Koji čimbenici utječu na kvalitetu suradnje učitelja i pomoćnika u nastavi? 


\section{Sudionici i postupak istraživanja}

Sudionici provedenog istraživanja bili su učitelji razredne i predmetne nastave te pomoćnici u nastavi sedam osnovnih škola iz triju gradova u Republici Hrvatskoj. Korištene smjernice prilikom odabira pojedinih škola su:

a) dosadašnja suradnja Centra inkluzivne potpore IDEM sa školama u uvođenju pomoćnika u nastavi (edukacijama pomoćnika i supervizijom koordinatora i pomoćnika u nastavi)

b) duljina iskustva škola u uvođenju pomoćnika u nastavi

c) broj pomoćnika u nastavi uškoli.

Za potrebe istraživanja konstruiran je Opći upitnik za pomoćnike u nastavi i Opći upitnik za učiteljekoji su provedeni u suradnji s koordinatorima škola. Na taj su se način željeli prikupiti podaci o nekim obilježjima pomoćnika odnosno učitelja te o školskom ozračju. Upitnikom za učitelje prikupljeni su podaci o zanimanju, iskustvu rada s učenicima s teškoćama, radu s pomoćnicima u nastavi i suradnji sa stručnom službom škole. Upitnikom za pomoćnike dobiveni su podaci o iskustvu rada s učenicima s teškoćama, o njihovom zanimanju, edukaciji za pomoćnike te vrsti zaposlenja i suradnji u školi. Konstruirani su upitnici provedeni na ukupno 81 učitelju i na 48 pomoćnika. Učitelji su kao sudionici fokus grupe odabrani na temelju dobivenih odgovora pri čemu su kriteriji bili dob, godine radnog iskustva, godine iskustva s pomoćnicima, razredna ili predmetna nastava i predmet koji učitelj predaje. Pomoćnici u nastavi su kao sudionici bili svi dostupni pomoćnici iz istih škola kao i učitelji.

U konačnici je formirano osam fokus grupa, tri grupe pomoćnika u nastavi te pet grupa učitelja. U kvalitativnom dijelu istraživanja sudjelovalo je ukupno 69 sudionika, 40 učitelja i 29 pomoćnika u nastavi. U svakom je gradu provedena jedna fokus grupa s pomoćnicima iz odabranih škola. U dva manja grada provedena je jedna fokus grupa s učiteljima iz obje škole, dok su u jednom većem gradu provedene tri fokus grupe u svakoj pojedinoj školi. Veličina pojedine fokus grupe iznosila je od 7 do 10 sudionika. Svi su sudionici dobrovoljno sudjelovali $\mathrm{u}$ istraživanju te se vodilo računa o povjerljivosti, tajnosti i anonimnosti podataka. Prilikom transkripcije materijala nije otkriven identitet osobe jer su dobivene izjave bilježene kodovima odnosno inicijalima i brojevima. Fokus grupe vođene su polustrukturiranim intervjuom za učitelje i pomoćnike u nastavi. Tematske cjeline intervjua za učitelje su: iskustvo učitelja u školi i u radu s pomoćnicima, opis rada pomoćnika, suradnja s pomoćnikom i stručnjacima za djecu s teškoćama, odnos pomoćnika i drugih učenika, odnos pomoćnika i roditelja, potrebna znanja, vještine i osobine pomoćnika. Tematske cjeline intervjua za pomoćnike u nastavi su: osposobljenost pomoćnika za rad, suradnja s učiteljima, koordinatorima i roditeljima, opis rada u razredu, potrebna znanja, vještine i osobine pomoćnika i perspektiva zanimanja.

Trajanje pojedine fokus grupe u svakoj od škola bilo je oko 1,5 sat pri čemu je jedna od suradnica ovog istraživanja, edukacijska rehabilitatorica, bilježila neverbalnu komunikaciju i važne prekretnice za vrijeme provedbe fokus grupnog intervjua, a voditeljica je istraživačkog projekta bila u ulozi moderatora. Svi dobiveni podaci bilježeni su audiozapisom nakon čega su snimke transkribirane.

\section{Metode obrade podataka}

S obzirom na postavljeni cilj i istraživačka pitanja koja iz njega proizlaze, u ovom istraživanju korišten je kvalitativni pristup prikupljanja podataka jer upravo navedena metoda omogućuje dobivanje što šire slike suradnje učitelja i pomoćnika. Mejovšek (2008) navodi osnovno polazište kvalitativne metodologije, a to je potpunije shvaćanje i dublje razumijevanje socijalne interakcije u prirodnom socijalnom kontekstu. U ovom je istraživanju odabrana analiza unaprijed definiranih okvira ili tema (Ritchie i Spencer, 1994; prema Ajduković i Urbanc, 2011). Takva se vrsta analize koristi u primijenjenim istraživanjima u području socijalnih politika kada 
Mateja Marinić, Klara Matejčić, Ljiljana Igrić KVALITETA SURADNJE UČITELJA I POMOĆNIKA U NASTAVI IZ.

je cilj doći do informacija koje su potrebne institucijama zaduženima za provedbu politika (Pope, Ziebland i Mays, 2000). Rezultati ovog istraživanja mogu poslužiti u regulaciji Pravilnika o pomoćnicima u nastavi i stručnim komunikacijskim posrednicima koji je propisalo Ministarstvo znanosti i obrazovanja.

Polazišta u postavljanju tema istraživačkog projekta „Uloga pomoćnika u nastavi iz perspektive učitelja i pomoćnika u nastavi“ bila su znanja i iskustva stručnjaka u svijetu (Velika Britanija, SAD) i dosadašnja praksa o ulozi pomoćnika u nastavi u inkluzivnoj školi u Hrvatskoj. Kako bi se dobio dublji uvid u navedeno područje istraživačkog interesa, postavljene su glavne teme kao početni okviri za kvalitativno prikupljanje i analizu podataka.

Tematska područja obuhvaćena kod učitelja:

1. Iskustvo učitelja u radu s učenicima s teškoćama i pomoćnicima u nastavi

2. Percepcija učitelja o učeniku

3. Percepcija učitelja o pomoćniku u odnosu na poslove i kompetencije pomoćnika

4. Suradnja pomoćnika

5. Suradnja učitelja.

Tematska područja obuhvaćena kod pomoćnika:

1. Iskustvo i osposobljenost pomoćnika u nastavi za rad

2. Percepcija pomoćnika o učeniku s teškoćama

3. Poslovi pomoćnika

5. Suradnja pomoćnika

6. Perspektiva zanimanja pomoćnika

7. Odnos pomoćnika s drugim učenicima.

Odabrane teme za analizu u svrhu ovog rada su:

- Suradnja učitelja s pomoćnikom u nastavi, tematsko područje Suradnja učitelja

- Suradnja pomoćnika s učiteljem, tematsko područje Suradnja pomoćnika.

Transkribirani materijal fokus grupnih intervjua zajedno s podacima općih upitnika i školske dokumentacije čini empirijsku građu. Podaci općih upitnika uneseni su u Excel tablice i NVivo 11 program, dok su sumarni podaci za pojedinu varijablu distribuirani u razrede. Razvojnom se interpretacijom dolazi do podrobnijeg razumijevanja uloge pomoćnika u današnjoj hrvatskoj školi, odnosno kvaliteti suradnje učitelja i pomoćnika, a komparativnom interpretacijom do spoznaje o sličnostima i razlikama perspektiva nastavnika i pomoćnika u nastavi, kao i unutar podskupina ovih dviju skupina sudionika u odnosu na odabrane teme. Jedinicu analize činila je izjava sudionika (dio ili cijela rečenica). Koraci korišteni u analizi građe su:

- upoznavanje s građom i uređivanje empirijske građe, izdvajanje bitnih izjava čitanjem transkripata

- identificiranje tematskih okvira unutar građe (ključnih pitanja, koncepata i tema) pri čemu se istraživači oslanjaju na postavljena istraživačka pitanja

- parafraziranje zapisa svih izdvojenih odgovora sudionika koji su se odnosili na suradnju učitelja i pomoćnika u nastavi

- kodiranje izdvojenih izjava s obzirom na teme - kodovi I. reda

- grupiranje kodova I. reda u kodove II. reda, odnosno kategorije

- povezivanje i interpretacija nalaza istraživanja prema temama Suradnja učitelja $s$ pomoćnikom u nastavi i Suradnja pomoćnika s učiteljima. 


\section{REZULTATI I RASPRAVA}

\section{Precepcija suradnje učitelja s pomoćnikom}

Unutar tematskog područjaSuradnjapomoćnika nalaze se sljedeće teme: Suradnja pomoćnika i učitelja, Suradnja pomoćnika i roditelja te Suradnja pomoćnika sa stručnim timom.

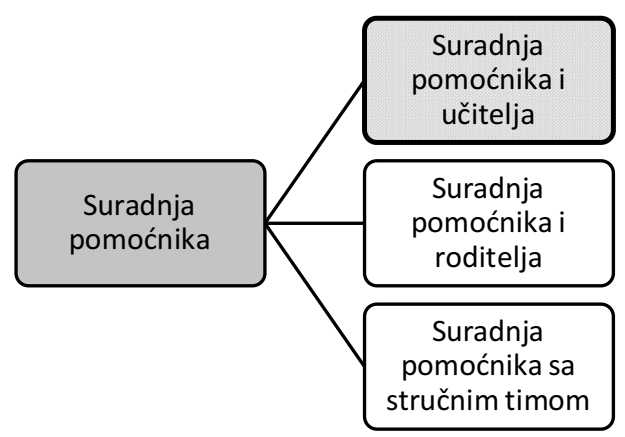

Slika 1. „Suradnja pomoćnika“ iz perspektive učitelja kao tematsko područje i pripadajuće teme

Za prikaz rezultata istraživanja odabrana je tema Suradnja pomoćnika i učitelja. Učitelji suradnju s pomoćnicima opisuju sljedećim kategorijama: Opće karakteristike suradnje, Zajednički poslovi, Vrijeme suradnje, Učitelj kao podrška pomoćniku u nastavi, Pomoćnik kao podrška učitelju, Poslovi pomoćnika koji su najpotrebniji te Mišljenje učitelja o utjecaju rada pomoćnika na kvalitetu nastave. U nastavku rada svaki će aspekt suradnje biti pojedinačno i detaljno opisan.

Tablica 1. Suradnja pomoćnika i učitelja iz perspektive učitelja te pripadajuće kategorije

\begin{tabular}{|l|l|c|}
\hline \multicolumn{1}{|c|}{ Tema } & \multicolumn{1}{|c|}{ Kategorije } & Frekvencije \\
\hline \multirow{4}{*}{$\begin{array}{l}\text { Suradnja } \\
\text { pomoćnika i } \\
\text { učitelja }\end{array}$} & Opće karakteristike suradnje & 22 \\
\cline { 2 - 3 } & Zajednički poslovi & 15 \\
\cline { 2 - 3 } & Vrijeme suradnje & 20 \\
\cline { 2 - 3 } & Učitelj kao podrška pomoćniku & 16 \\
\cline { 2 - 3 } & Pomoćnik kao podrška učitelju & 14 \\
\cline { 2 - 3 } & Poslovi pomoćnika koji su najpotrebniji & 6 \\
\cline { 2 - 3 } & Mišljenje učitelja o utjecaju rada pomoćnika na kvalitetu nastave & \multicolumn{2}{|c|}{6} \\
\hline
\end{tabular}

\section{Opće karakteristike suradnje}

Kada su učitelji govorili o suradnji s pomoćnicima u nastavi, više od pola njihovih izjava je upućivalo na ono što bi se moglo svrstati u opće karakteristike suradnje. Učitelji izražavaju zadovoljstvo time što surađuju s pomoćnikom i drago im je što se u razredu nalazi još jedna osoba koja im pomaže u neposrednom radu. No, podrobnije gledajući, suradnja se iskazala specifičnom za pojedinu fokus grupu i tu se dolazi do različitih pojedinačnih primjera. Jedna sudionica istraživanja navodi kako joj je „ponekad, u suradnji s asistentom, teško reći što joj se ne sviđa u njegovom radu. "Komunikacija se pokazala kao čimbenik koji uvelike utječe na kvali- 
Mateja Marinić, Klara Matejčić, Ljiljana Igrić KVALITETA SURADNJE UČITELJA I POMOĆNIKA U NASTAVI IZ.

tetusuradnje. Neki učitelji nisu uspjeli ostvariti dobru komunikaciju kao u prethodno navedenom primjeru, dok drugi ističu kako pomoćnici vole pitati učitelje za savjet te pod školskim odmorom često razmjenjuju informacije i razgovaraju o radu. Ono što je karakteristično za učitelje i pomoćnike jest njihova neverbalna komunikacija tijekom sata. Istraživanje je pokazalo kako mnogi učitelji i pomoćnici tijekom nastavnog sata, odnosno određene aktivnosti, neverbalno komuniciraju što im omogućava praćenje međusobnog rada i pružanje međusobne podrške; primjer sudionika koji ističe da „pomoćnik signalizira kad učeniku u obrazovnom dijelu nešto treba."Također, učiteljica se "tijekom sata neverbalno sporazumijeva s asistentima u situacijama kada on nije siguran smije li u nečemu pomoći." Osim navedenog, jedan primjer sudionice ističe kako ona "opominje asistenticu da tiše radi s učenikom" što pokazuje drugačiji aspket komunikacije učitelja i pomoćnika, a time i njihovog međusobnog odnosa, suradnje i podržavanja unutar razredne zajednice. Usklađivanje rada učitelja i pomoćnika unutar razredne zajednice izazov je i govori nam koliko je potrebno ozbiljno shvatiti tematiku suradnje učitelja i pomoćnika. Mnogim je učiteljima izazovno komunicirati one aspekte rada koje bi voljeli unaprijediti zbog bojazni da bi narušili odnos s pomoćnicima. Učitelji koji nisu ostvarili suradnju kao razlog navode nedostatak vremena ili izostanak komunikacije s pomoćnikom što dovodi do izostanka suradnje. Kao što primjer jedne učiteljice kaže: „zbog nedostatka vremena ne može surađivati s asistentom. "Takvi primjeri pozivaju na uzbunu stručnjake i institucije zadužene za kreiranje obrazovnih politika i njihovo uređenje. Učitelji i pomoćnici moraju jedno u drugome prepoznati partnera koji zajedničkim radom unaprjeđuje i podiže kvalitetu izvođenja nastave na novu razinu, a ne kao ometajuće faktore u radu koji pretpostavljaju još jednu dodatnu obvezu za koju učitelji nemaju vremena.

Postoje razlike u općim karakteristikama suradnje s obzirom na pojedine fokus grupe. Možemo ih pripisati različitim osobinama ličnosti koje učitelji i pomoćnici imaju i unose ih u suradnju, ali i njihovoj osviještenosti o važnosti zajedničkog rada s ciljem osiguravanja inkluzivnog pristupa odgoju i obrazovanju.

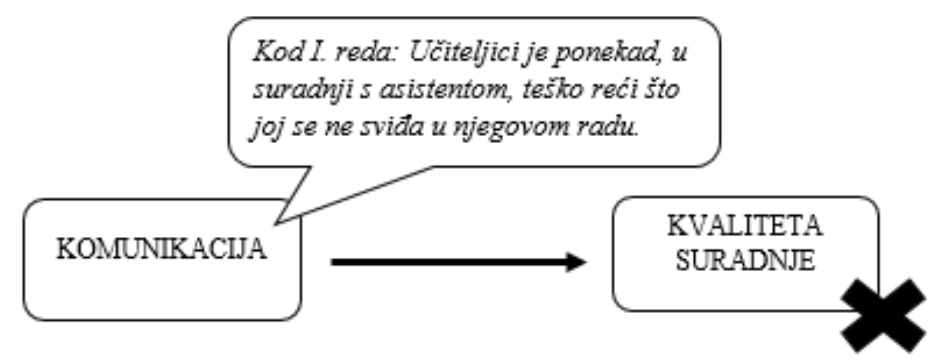

Slika 2. Odnos komunikacije i kvalitete suradnje na temelju izjave sudionika istraživanja

\section{Zajednički poslovi}

$\mathrm{U}$ učionici učitelj i pomoćnik u nastavi odgovorni su za poučavanje i neposredni rad s učenicima pa sukladno tomu postoje zajednički poslovi u kojima blisko surađuju. Nešto manje od polovice učitelja tijekom fokus grupe iskazalo je kako s pomoćnikom zajednički prilagođavaju rad, istražuju potrebe učenika, vode računa o postupnom uvođenju novih pojmova u nastavno gradivo, što pokazuje primjer gdje „učitelj u suradnji s asistentom vodi računa o postupnosti, tako su započeli s pokazivanjem na karti određenog pojma kad je učenik stekao tu sposobnost", izrađuju nastavni materijal, reduciraju količinu gradiva te ga prilagođavaju učenikovim sposobnostima. Navedeni primjeri ističu dobru praksu koja bi svakodnevno trebala biti prisutna. No važno je istaknuti i primjer gdje suradnja pomoćnika i učitelja nije usklađena $s$ inkluzivnim načelima, učiteljica "nastavu izvodi posebno za učenika s teškoćama i posebno za 
ostatak razreda uz pomoć asistentice." U navedenom se primjeru ogleda nedostatak podrške tom učitelju i pomoćniku. Njihova suradnja može i mora biti osigurana podrškom stručne službe škole, ali i u obliku mobilnog stručnog tima, odnosno stručnog suradnika s kompetencijama i znanjima inkluzivnog obrazovanja i poznavanja razvoja učenika s posebnim odgojno-obrazovnim potrebama. Ako polazimo od inkluzivnih načela odgoja i obrazovanja, onda se u praksi ne mogu događati primjeri zasebnog izvođenja nastave za učenika s posebnim odgojno-obrazovnim potrebama koji je odvojen od svoje grupe vršnjaka.

Učitelj i pomoćnik surađuju prilikom provjere znanja učenika. Postoje razlike u tom području s obzirom na fokus grupe. One koje su ga istaknule, navode kako s pomoćnikom surađuju u izradi ispita znanja, traže prikladne trenutke za usmenu provjeru i pomoćnik pruža podršku prilikom pisane provjere. Jedan primjer učiteljice potvrđuje kako "pisano provjerava znanje učenice u radu s asistenticom jedan na jedan."

Učitelji koji imaju iskustvo u radu s učenicima s poteškoćama u ponašanju i emocionalnoj regulaciji isticali su kako pružaju podršku pomoćniku u nastavi, odnosno „pomažu pomoćniku u nastavi u smirivanju učenika kada primijeti da on (pomoćnik) to ne uspijeva sam", također „asistentica i nastavnica zajedno rade na usmjeravanju učenika da izvrši zadatak. " Učitelj i pomoćnik zajedno uočavaju trenutno psihofizičko stanje učenika te uočeno stanje uzimaju u obzir prilikom izvršavanja zadataka tijekom nastavnog sata. Jedna učiteljica navodi da „kada učenik ima loš dan, ona i pomoćnica mu se prilagode."

\section{Vrijeme suradnje}

Polovina učitelja u opisu suradnje s pomoćnikom navodi vrijeme suradnje. Ono se odvija uglavnom prije početka sata, tijekom sata, na kraju sata i na tjednoj razini. Najveći broj učitelja navodi kako s pomoćnikom surađuju neposredno prije početka sata kada im daju upute i materijale za rad, no u nekim slučajevima pomoćnici prve upute za rad dobivaju tek tijekom sata. U tim primjerima ne možemo govoriti o dobroj suradnji ako se ona odvija prije početka sata ili tijekom sata. Posao pomoćnika zahtijeva jednaku pripremu kao i posao učitelja, on ne može pružiti dovoljno dobru podršku niti dobro primijeniti nastavni sadržaj ako se s tim istim zadacima i sadržajem upoznaje na licu mjesta. Navedena situacija dovodi u pitanje i ostvarenost postavljenih ciljeva za pojedinog učenika. Potrebno je bolje promišljanje o sadržaju i načinu rada, definiranje ciljeva i jasnih aktivnosti kako bi pomoćnik mogao dobro prenijeti nastavni sadržaj učeniku i voditi ga za vrijeme nastavnog procesa. Nadalje, učitelji u manjem broju surađuju s pomoćnikom na kraju sata, tek nekoliko njih ističe da s pomoćnikom razgovaraju o riješenim zadacima i potrebi za promjenom težine zadataka za pojedinog učenika. Završetak nastavnog sata može podrazumijevati kratku povratnu informaciju pomoćnika, ali to je samo površinski ako se učitelj i pomoćnik oslanjaju na takav način rada. Nekoliko je učitelja istaknulo kako s pomoćnikom surađuje isključivo na tjednoj razini. Glavni je uzrok tome nedostatak vremena, odnosno nedovoljno prostora unutar tjednog zaduženja učitelja koje bi se odvojilo za razgovor s pomoćnikom.

\section{Učitelj kao podrška pomoćniku u nastavi}

Daljnji su rezultati pokazali kako se malo manje od polovine učitelja iskazuje kao podrška pomoćniku u nastavi. Taj oblik podrške karakterizira uvođenje u rad i podrška u svakodnevnom radu te praćenje rada pomoćnika. Podrška u svakodnevnom radu pomoćnika ogleda se u uvođenju u način rada, osiguravanju materijala i davanju uputa za rad, što možemo vidjeti iz primjera učiteljice koja navodi kako su "pomoćnici dobili prilagođeni program da mogu pratiti nastavne teme." Neki učitelji pomoćnicima dopuštaju samostalno donošenje odluka u određenim situacijama s ciljem uspostavljanja ravnopravnosti odnosa učitelj - pomoćnik, odnosno kako bi prema navodu učiteljice „učenici shvatili da je asistent ravnopravan učiteljici." Mnogi 
Mateja Marinić, Klara Matejčić, Ljiljana Igrić KVALITETA SURADNJE UČITELJA I POMOĆNIKA U NASTAVI IZ.

učitelji daju savjete pomoćniku kako raditi s učenikom s posebnim edukacijskim potrebama, primjerice „(pomoćnik) je tražio savjete za rad s obzirom da u vrtiću nije imao podršku. " Kada su učitelji govorili o praćenju rada pomoćnika s učenikom, isticali su da tijekom sata povremeno dolaze do pomoćnika i učenika kako bi mu pružili potrebnu podršku i pratili rad, što je vidljivo iz primjera učiteljice koja ",tijekom sata prati rad učenika i asistenta, sugerira i komentira što je dobro, a što nije u redu"; ali se događa i primjer gdje učiteljica upozorava pomoćnika da ne smije pomagati drugim učenicima. U pojedinim se školama takav oblik rada pomoćnika ne podržava jer je općeprihvaćeno mišljenje da pomoćnik pruža podršku isključivo učeniku s teškoćama, što nije praksa u zemljama koje već godinama imaju pomoćnike i gdje se jasno iskazuje kako je on dodatan oblik pomoći učitelju i cjelokupnom razredu.

\section{Poslovi pomoćnika koji su najpotrebniji}

Pojedine fokus grupe učitelja iznijele su mišljenje o tome koji se poslovi pomoćnika smatraju najpotrebnijima. Trećina sudionika smatra kako je pomoćnik najkorisniji u smirivanju učenika i regulaciji njegovog ponašanja, a to znači „da kada učenik impulzivno reagira, pomoćnik ga smiruje ili usmjerava na drugu aktivnost." Ono što također naglašavaju jest njegova podrška u usmjeravanju učenikove pozornosti na zadatak ili rad učitelja. Kako jedna učiteljica navodi, „da je dijete bez pomoćnika prepušteno samome sebi i nema nekoga da ga usmjerava u radu." Posljedično, učitelji ističu kako se na taj način mogu bolje posvetiti radu s ostatkom razreda što je vidljivo iz izjave učiteljice da "pomoćnica najviše pomaže u radu s učenikom s teškoćom jer se tako može posvetiti radu s ostatkom razreda."

\section{Pomoćnik kao podrška učitelju}

Kako je učitelj podrška pomoćniku, tako je i pomoćnik podrška učitelju prilikom izvršavanja svakodnevnih poslova. Sudionici istraživanja navodili su kako „pomoćnici daju učiteljima upute kako raditi s učenikom s posebnim edukacijskim potrebama" te da "neki pomoćnici najbolje prepoznaju što učenik u određenom trenutku može svladati" stoga učitelji prihvaćaju upute i mišljenje pomoćnika. Primjer pomoćnice u nastavi, apsolventice edukacijske rehabilitacije, koja je svojim radom utjecala na učiteljicu te je učiteljica zatim usvojila inkluzivni pristup u kojem je važno uspostaviti kontakt sa svim učenicima kao preduvjet prihvaćanja učenika $s$ teškoćama u razredu. Navedeni aspekt suradnje, gdje je pomoćnik podrška učitelju, posebno dolazi do izražaja kod učitelja predmetne nastave koji u pomoćniku vide podršku prilikom prelaska učenika iz razredne u predmetnu nastavu, „pomoćnik najbolje prepoznaje što učenik u određenom trenutku može svladati i to učitelj uzima u obzir." Važno je istaknuti kako to nije prava uloga pomoćnika, ali se ona javlja u praksi zbog nedovoljne podrške usmjerene učiteljima koji bi trebali blisko surađivati sa stručnjakom za metodičku prilagodbu odnosno edukacijskim rehabilitatorom.

\section{Mišljenje učitelja o utjecaju pomoćnika na kvalitetu nastave}

Posljednji aspekt suradnje učitelja i pomoćnika iz perspektive učitelja jest njihovo mišljenje o utjecaju pomoćnika na kvalitetu nastave. Ono što se u provedenom istraživanju pokazalo, na temelju izjava sudionika, jest da uključenost i kvalitetan rad pomoćnika pozitivno utječe na rad učitelja, odnosno pomoćnik je taj koji učitelju olakšava izvođenje nastave. Sudionici su isticali kako rad nije moguć bez podrške pomoćnika. Rad učitelja olakšan je uz njegovu nazočnost pa se oni mogu lakše usredotočiti na rad s ostatkom razreda. Kada pomoćnik nije prisutan, učitelj se tada mora simultano usmjeriti na rad učenika s teškoćama i na rad ostalih učenika. No važno je istaknuti kako jedan sudionik istraživanja ističe da rad pomoćnika i učenika ponekad ometa nastavni proces te ih on tada premjesti u kabinet kako bi mogli raditi odvojeno. Iz navedenoga možemo vidjeti kako postoji raznolikost u mišljenju učitelja o pomoćnicima 
njihovom utjecaju na kvalitetu provođenja nastavnog procesa u koji su uključeni učenici različitih mogućnosti i potreba.

\section{Percepcija suradnje pomoćnika s učiteljem}

U poglavlju koje slijedi donosi se analiza rezultata sudionika Pomoćnika u nastavi. Unutar tematskog područja Suradnjapomoćnika dobivene su teme: Suradnja pomoćnika i učitelja, Suradnja pomoćnika i roditelja i Suradnja pomoćnika sa stručnim timom.

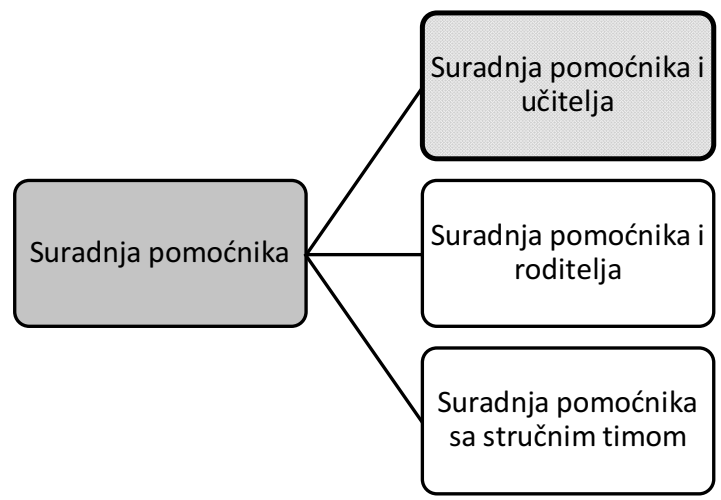

Slika 3. „Suradnja pomoćnika“ iz perspektive pomoćnika u nastavi kao tematsko područje i pripadajuće teme

Pomoćnici suradnju s učiteljima opisuju sljedećim kategorijama: Opće karakteristike suradnje, Zajednički poslovi, Vrijeme suradnje, Učitelj kao podrška pomoćniku, Pomoćnik kao podrška učitelju.

Tablica 2. Suradnja pomoćnika i učitelja iz perspektive pomoćnika te pripadajuće kategorije

\begin{tabular}{|l|l|c|}
\hline Tema & Kategorije & Frekvencije \\
\hline \multirow{4}{*}{ Suradnja pomoćnika i učitelja } & Opće karakteristike suradnje & 18 \\
\cline { 2 - 3 } & Zajednički poslovi & 24 \\
\cline { 2 - 3 } & Vrijeme suradnje & 4 \\
\cline { 2 - 3 } & Učitelj kao podrška pomoćniku & 4 \\
\cline { 2 - 3 } & Pomoćnik kao podrška učitelju & 3 \\
\hline
\end{tabular}

\section{Opće karakteristike suradnje}

Više od polovine pomoćnika, govoreći o suradnji s učiteljem, ističu koliko su njome zadovoljni. Kao i kod učitelja, uglavnom navode pozitivna iskustva koja karakteriziraju "odlična suradnja“ i „korektan odnos“. Jedna sudionica istraživanja navodi kako se "osjeća važno u suradnji s učiteljem. "Neki su sudionici istaknuli kako suradnja ovisi o spremnosti učitelja na suradnju. Važno je istaknuti da je suradnja učitelja i pomoćnika u nastavi neophodna jer je ona temelj suradničkog poučavanja. Ako pojedini učenici iskazuju potrebu za prilagodbom nastavnog sadržaja i metoda poučavanja, neovisno o tome je li učenik dobio rješenje o primjerenom 
Mateja Marinić, Klara Matejčić, Ljiljana Igrić KVALITETA SURADNJE UČITELJA I POMOĆNIKA U NASTAVI IZ.

obliku školovanja, učitelj i pomoćnik su ti koji zajedničkim radom i suradnjom osiguravaju zadovoljenje tih istih potreba učenika. Pomoćnik ne može djelovati samostalno u radu s učenikom niti je njihova suradnja zamišljena kao dobrovoljno djelovanje o kojem učitelj donosi odluku hoće li surađivati ili ne. Zbog toga možemo pretpostaviti kako još uvijek učitelj i pomoćnik unutar učionice djeluju „odvojeno“ i svaki radi za sebe, pri čemu je učitelj usmjeren na podučavanje nastavnog plana i programa ostatka razreda, a pomoćnik je u većini slučajeva smješten pored učenika s teškoćom te ga on zasebno poučava. Takva separacija nije slika suradnje ni inkluzivne kulture rada.

Gledajući kvalitetu suradnje, dobiveni su različiti navodi u pojedinoj fokus grupi pomoćnika u nastavi. Jedna pomoćnica ističe da ima „odličnu suradnju s učiteljicom koja joj pomaže koliko može" dok druga navodi da je suradnja "dobra, jer se međusobno uvažavaju i razumiju." Sličnost pronalazimo i u navodu pomoćnice koja ističe pozitivan primjer suradnje koja je "jako dobra, (učiteljica) unaprijed kaže što će se raditi, nekad (učiteljica) prepušta inicijativu asistentici." No zanimljivo je istaknuti kako se jedan pomoćnik "trudi biti neprimjetan učiteljima $i$ učeniku." Takav pristup radu nije poželjan. Pomoćnik u nastavi nije djelatnik koji svoju aktivnost u razredu mora svesti na minimum kako ne bi ometao nastavni proces. Podrška pomoćnika u nastavi usmjerena je prema učeniku s posebnim edukacijskim potrebama, grupi učenika, ali i cjelokupnom razredu. Dogovor učitelja i pomoćnika o načinu rada, zajedničko planiranje aktivnosti i zadataka potiče pomoćnika na aktivan pristup radu i sprječava pasivnost, odnosno „neprimjetno sjedenje u pozadini učionice.”

Osim u kvaliteti suradnje, pronalazimo navode koji govore o području komunikacije pomoćnika i učitelja. Iz perspektive pomoćnice potrebno je da komunikacija „između učitelja i asistenata bude bolja, čemu bi pomogla bolja pripremljenost jednih i drugih." Koliko je neophodno raditi na vještinama komunikacije, pokazuju i navodi pomoćnika da se „ponekad dogode nesporazumi u prenošenju informacija", ali s druge strane jedan sudionik iskazuje kako "uviđa neke greške u komunikaciji i razmišlja kako se one mogu spriječiti." Osim što učitelj i pomoćnik tijekom nastavnog sata komuniciraju verbalnim putem, pokazalo se da velik dio komunikacije čini i ona neverbalna, kada primjerice „asistentica pogledom traži pomoć učiteljice." Možemo vidjeti kako učitelj i pomoćnik ovise i o neverbalnom dijelu odnosno sporazumijevanju tijekom različitih aktivnosti u koje su uključeni svi učenici ili grupa učenika. Dobra je komunikacija preduvjet adekvatnog rješavanja prepreka i izazova u radu s učenicima. Ona utječe na kvalitetu i sveukupno zadovoljstvo radom i suradnjom. Pomoćnica u istraživanju navodi da je „jako zadovoljna komunikacijom s učiteljicom jer se već i pogledom razumiju te tako znaju kako raditi s učenikom"što dodatno potvrđuje njezinu važnost.

Istraživanje je pokazalo kako postoje i primjeri izostanka suradnje učitelja i pomoćnika. Sudionik istraživanja ističe kako se on i učiteljica "ne dogovaraju o radu", a primjer jedne pomoćnice govori kako "više ne surađuje s razrednicom." lako ih je u ovom istraživanju bilo u manjem broju, ne smijemo ih zanemariti jer upravo oni govore koliko je stručne podrške potrebno pružiti učiteljima i pomoćnicima u njihovom svakodnevnom radu.

\section{Zajednički poslovi}

Kada su opisivali suradnju, gotovo su svi pomoćnici istaknuliposlove koje dijele s učiteljem, odnosno one u kojima blisko surađuju. Pomoćnici su jasno naveli kako „neki učitelji prilagođavaju sadržaje, a neki prepuste prilagodbe asistentu jer smatraju da on najbolje poznaje dijete”, također "za određene predmete, kao što su Povijest, Geografija, Kemija i Biologija, asistentica sažima i pojednostavljuje sadržaj."Iz navedenih primjera možemo vidjeti kako jedan dio pomoćnika u nastavi samostalno prilagođava nastavni materijal jer prema mišljenjima učitelja pomoćnici su ti koji najbolje poznaju učenika pa sukladno tomu zadatke prepuštaju upravo njima.No takav način rada nije u skladu s praksom i ne može biti dozvoljen bez podrške stručne službe (koordinatora - edukacijskog rehabilitatora) i svakodnevne podrške učitelja. S 
druge strane, postoji dio učitelja koji „s asistenticom provjeravaju izbor sadržaja koje će dati učeniku" te također "asistentica i učiteljica unaprijed se dogovaraju što će raditi." Prilagodba sadržaja i načina poučavanja vrlo je raznolika i nije podudarna među fokus grupama. Proteže se od toga da pomoćnik samostalno priprema nastavni materijal, da učitelj i pomoćnik zajedno surađuju i da se dogovaraju oko nastavnog materijala, prema tome da učitelj samostalno pripremi materijale, a pomoćnik pruža podršku učeniku prilikom rješavanja zadataka. Kao što jedna pomoćnica navodi: „Učitelji imaju pripremljene sadržaje, a uloga je pomoćnika da provjerava jesu li učenici napravili ono što je zadano." Prema prikazanom vidimo da je praksa raznolika. Primjerice, pomoćnik koji pruža podršku učeniku s motoričkim teškoćama nije zadužen samo za osiguravanje mobilnosti. Njegova uloga u školi odnosno suradnja s učiteljem znatno je šira. Ono što je potrebno, jest sustavno uređenje i jasno definiranje zadaća i uloga učitelja u suradnji s pomoćnikom. Rad pomoćnika ni u jednoj školi nije isti, a moramo imati na umu da svi dobivaju jednaku naknadu za svoj rad.

Pomoćnici i prilikom provjere znanja učenika s posebnim edukacijskim potrebama surađuju s učiteljem. Jedan dio pomoćnika samostalno priprema potrebne materijale za provjeru znanja, dok drugi dio u dogovoru s učiteljem priprema ispitna pitanja. Zajedno surađuju u procjeni znanja, posebice prilikom prelaska učenika u predmetnu nastavu. Dodatno, neki pomoćnici preuzimaju inicijativu i predlažu sadržaje za ispit. Kao i kod prilagodbe sadržaja i načina podučavanja, vidimo kako se provjera znanja u suradnji s učiteljem ogleda u različitim primjerima iz prakse.

\section{Vrijeme suradnje}

Svega nekoliko pomoćnika u nastavi djelomično se osvrnulo i na vrijeme suradnje $s$ učiteljem dok su učitelji tom aspektu tijekom fokus grupnog intervjua pridali veću pozornost, odnosno češće o tome govorili. Jedna pomoćnica ističe kako, učiteljica (asistentici) govori što da radi uglavnom kad započne nastava" te "učiteljica povremeno najavi temu za idući dan."Iz gledišta pomoćnika možemo zaključiti kako se dogovori i suradnja odvijaju povremeno, prije početka sata ili tijekom sata. Nailazimo i na primjer pomoćnice koja je u razrednoj nastavi i "učiteljica joj prije sata ne govori što će raditi." S obzirom na to da su se pomoćnici u manjem broju osvrnuli na taj aspekt suradnje, iz njihove perspektive možemo zaključiti koliko im takva suradnja nedostaje.

\section{Pomoćnik kao podrška učitelju}

Pomoćnik i učitelj jedan drugome su međusobna podrška u radu. Navedeni su aspekt suradnje prepoznali neki pomoćnici te ga istaknuli u provedenom istraživanju navodeći kako određeni učitelji samoinicijativno traže podršku pomoćnika jer smatraju da je on taj koji dobro poznaje učenika i koji ga može upoznati s njegovim potrebama. Neki učitelji predmetne nastave iznimno cijene iskustvo pomoćnika koji je s učenikom došao iz razredne nastave. Pokazalo se da upravo u tom razdoblju tranzicije dolazi do razmjene iskustava između pomoćnika i učitelja predmetne nastave, što možemo vidjeti iz primjera gdje pomoćnik ističe „da su učitelji predmetne nastave sami tražili podršku (pomoćnika) na temelju preporuke razredne učiteljice."Koliko je dobro što je pomoćnik izvor korisnih informacija za učitelje, toliko moramo imati na umu da suradnja iz razredne u predmetnu nastavu mora obuhvaćati učitelja razredne nastave, učitelja predmetne nastave, koordinatora za pomoćnike i samog pomoćnika. Dobra priprema na početku školske godine u vidu timskog sastanka postavila bi temelj za daljnju suradnju učitelja predmetne nastave i pomoćnika pri čemu bi se izbjegao osjećaj da je pomoćnik nositelj svih informacija o učeniku koje prenosi od jednog do drugog učitelja. 
Mateja Marinić, Klara Matejčić, Ljiljana Igrić KVALITETA SURADNJE UČITELJA I POMOĆNIKA U NASTAVI IZ.

\section{Učitelj kao podrška pomoćniku u nastavi}

Učitelj je podrška pomoćniku u njegovom svakodnevnom radu s učenicima, daje mu savjete, usmjerava ga i pomaže mu u izvršavanju zadataka koji se odnose na nastavni sadržaj. Nekoliko pomoćnika u nastavi istaknulo je kako se podrška učitelja usmjerena prema njima ogleda i prilikom regulacije ponašanja učenika jer kada „asistentica ne može smiriti učenika, učiteljica joj u tome pomaže." Jedna sudionica istaknula je kako učiteljica podržava "rad s drugom djecom i sudjelovanje u radu pred pločom." Navedeni primjer na dobar način opisuje suradnju učitelja i pomoćnika, odnosno koju ulogu učitelj ima kada u svom razredu ima pomoćnika i kako ga može poticati na aktivno sudjelovanje i uključivanje u cjelokupnu razrednu zajednicu. Važno je napomenuti kako nisu sve fokus grupe odnosno pomoćnici isticali taj aspekt suradnje.

\section{RASPRAVA}

Kao što je spomenuto, učitelji predmetne nastave često se oslanjaju na podršku pomoćnika u nastavi, ponegdje u tolikoj mjeri da većinu posla prepuste pomoćniku (prilagodbe sadržaja, provjere znanja i sl.) jer njega smatraju osobom koja najbolje poznaje učenika. Takva praksa može se javiti kod pomoćnika s opsežnom edukacijom od 218 sati i dužim iskustvom rada $s$ učenikom $s$ teškoćama jer on je taj koji je upoznat $s$ učenikovom razinom znanja, onime što može svladati te s potrebnom prilagodbom koja njemu najbolje odgovara. To je učiteljeva percepcija pomoćnika u nastavi i način na koji on pristupa suradnji s njime. Neupitna je podrška i znanje pomoćnika (primjerena edukacija) u procesu poučavanja, ali je važno znati da su učitelji ti koji moraju poznavati učenikove potrebe, vještine, razinu kompetencija i prema tome usklađivati, zajedno s pomoćnikom, prilagođavati nastavni plan i program i pratiti napredak.

Do prepreke u suradnji učitelja predmetne nastave i pomoćnika dolazi zbog načina na koji je predmetna nastava organizirana. Pomoćnik nema dovoljno vremena u danu, a ni predviđenu satnicu da bi mogao odvojiti vrijeme za pojedinog učitelja predmetne nastave te s njim dogovarati i planirati podršku. lako je podrška koju učitelj daje pomoćniku u predmetnoj nastavi prepoznata, važno je naglasiti da je ona ujedno i odraz njihove nedovoljne pripremljenosti na dolazak učenika s posebnim edukacijskim potrebama u više razrede. Pomoćnik ne može biti jedini izvor podrške i informacija o funkcioniranju učenika, iako s njim provodi mnogo vremena u neposrednom radu. $U$ tom je primjeru važno naglasiti timski rad stručne službe, učitelja i pomoćnika u nastavi. U konačnici je potrebno zadovoljiti i osnovnu stavku, a to je regulacija satnice predviđene za rad pomoćnika koja podrazumijeva i pripremu za rad, odnosno suradnju s učiteljima i stručnim timom škole.

S obzirom na iskustva učitelja i njihovu suradnju s pomoćnicima u nastavi, a sukladno dobivenim kategorijama i pripadajućim kodovima obje skupine sudionika, možemo oblikovati jedinstven prikaz njihove suradnje. Grafički prikaz (Slika 4.) nastoji predočiti međusobnu povezanost kategorija kao i njihov međusobni utjecaj.

Opće karakteristike suradnje (1), koje se temelje na vještinama komunikacije, zadovoljstvu i kvaliteti suradnje, utječu na zajedničke poslove učitelja i pomoćnika. Koliko će se učitelj i pomoćnik uključiti u zajedničko planiranje rada, pružanje podrške učeniku s posebnim edukacijskim potrebama u vidu prilagodbe sadržaja i metoda podučavanja, kao i podrške u ponašanju, ovisi o, primjerice, načinu na koji su učitelj i pomoćnik ostvarili komunikaciju, koliko su zadovoljni što zajedno rade. Ako komunikacija izostaje, opseg zajedničkih poslova bit će malen, a kvaliteta pružene podrške bit će niska. Vrijeme suradnje (3) i Zajednički poslovi (2) međusobno djeluju jedno na drugo. Istraživanje je pokazalo kako se suradnja učitelja i pomoćnikaglede neposrednog rada s učenikom odvija netom prije početka nastavnog sata ili u njegovoj prvoj polovici. U tom vremenu učitelj i pomoćnik dogovaraju zadatke i aktivnosti te shodno njima 
postavljene ciljeve. Ako je vrijeme za suradnju ograničeno, što je provedeno istraživanje pokazalo, zajednički poslovi oko sadržaja i metoda rada, provjere znanja i sl. gube kvalitetu. Vrijeme u kojem će učitelj i pomoćnik moći dobro raspraviti aktivnosti i ciljeve, metode rada i potrebne prilagodbe za pojedinog učenika podiže profesionalnost na novu razinu koja uzima u obzir kvalitetno odrađen posao. Učitelji koji koriste podršku pomoćnika i prepoznaju njegovu važnost u odgojno-obrazovnom procesu lako navode koji su poslovi pomoćnika prema njima najpotrebniji (4). Prema provedenom istraživanju to je usmjeravanje učenikove pozornosti na nastavni proces i gradivo te regulacija ponašanja učenika koji je uz pomoćnika mirnijeg ponašanja.

Opće karakteristike suradnje (1), Zajednički poslovi (2) i Poslovi pomoćnika koji su najpotrebniji (4) utječu na Mišljenje učitelja o utjecaju pomoćnika na kvalitetu nastave (5). Ako je učitelj prihvatio pomoćnika u svojoj razrednoj zajednici, cijeni i prepoznaje važnost njegove uloge, uključuje ga u planiranje nastavnog procesa, onda možemo zaključiti kako je mišljenje učitelja o utjecaju na kvalitetu nastave pozitivno. Oni učitelji koji nisu prihvatili pomoćnika, odnosno nisu ga na ispravan način uključili u razrednu zajednicu, uglavnom smatraju, ili su podložni tome, da je pomoćnik taj koji svojim radom ometa nastavni proces te ga učitelj potencijalno može isključivati iz razredne zajednice preusmjeravajući njegov rad s učenikom na hodnik škole, knjižnicu ili kabinet edukacijskog rehabilitatora - stručnog suradnika.

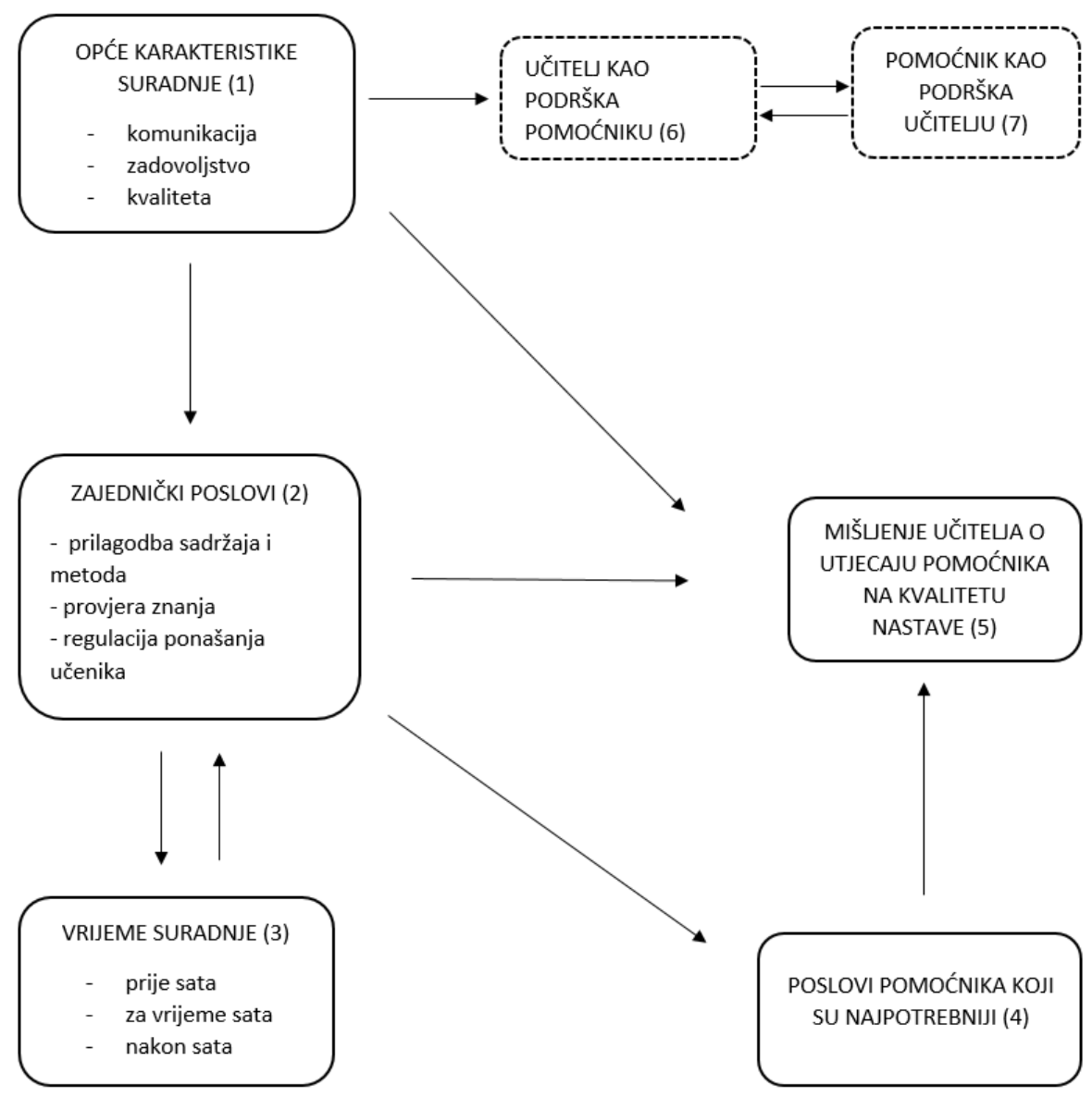

Slika 4. Grafički prikaz modela suradnje učitelja i pomoćnika 
Mateja Marinić, Klara Matejčić, Ljiljana Igrić KVALITETA SURADNJE UČITELJA I POMOĆNIKA U NASTAVI IZ..

U konačnici, učitelj i pomoćnik jedno drugome su međusobna podrška $(6,7)$. Koliko će učitelj biti podrška pomoćniku, ovisi o tome koliko je njihova komunikacija uspješna, koliko su zadovoljni time što surađuju i načinom na koji surađuju. Učitelji su istaknuli kako pružaju, ali i primaju podršku pomoćnika. Važno je imati na umu da je, hijerarhijski gledano, pomoćnik u nižoj poziciji od učitelja. Učitelji su ti koji su vođe timskog rada i modeli profesionalnog odnosa prema radu. Pomoćnik će se dobro osjećati u radnom okruženju koje nudi prostor za napredak, usvajanje novih znanja i podršku u odgojno-obrazovnom radu s učenikom s posebnim edukacijskim potrebama. Takvi uvjeti, u konačnici, postavljaju i kvalitetno pružanje podrške pomoćnika.

U skladu s postavljenim istraživačkim pitanjem možemo konstatirati da je suradnja učitelja i pomoćnika u praksi raznolika i specifična za svaku pojedinu školu. Koliko će biti dobra i time usmjerena na pružanje podrške cijeloj razrednoj zajednici, ovisi o pojedinačnom primjeru, odnosno dodatnom angažmanu učitelja i pomoćnika. Pojedini aspekti suradnje podudaraju se među grupama učitelja i pomoćnika. Ono u čemu se grupe djelomično slažu jest vrijeme suradnje, zajednički poslovi i podrška učitelja pomoćniku. U konačnici možemo utvrditi kako suradnja ničim nije regulirana niti se u školama prepoznaje kao temelj „suvremenog poučavanja”.

Analizom dobivenih podataka te njihovom usporedbom s općim karakteristikama škola unutar istraživanja možemo istaknuti čimbenike koji utječu na kvalitetu suradnje učitelj - pomoćnik u nastavi. Prije svega, to su (1) duljina iskustva učitelja u radu s učenicima s teškoćama te u (2) radu s pomoćnicima, odnosno oni koji rade i surađuju duže od pet godina. Iskustvo im omogućava da unaprijed predvide koja bi područja suradnje mogla predstavljati izazov, primjerice komunikacija, i time ukloniti moguće teškoće. Također, učitelji i pomoćnici s dužim iskustvom pokazuju bolje viđenje suradnje što znači da lakše uočavaju i prepoznajuizazove u radu te potrebne preduvjete za unaprjeđenje suradnje. Primjerice, učitelji koji su godinama surađivali s pomoćnikom već unaprijed znaju kako novog pomoćnika moraju uvoditi u način rada, odnosno educirati ga o osnovnim načelima rada škole, o metodama rada i poučavanja kao i upoznati ga s nastavnim sadržajem. Učitelji koji su surađivali s pomoćnicima do jednu godinu naglasili su kako se povremeno događaju pogreške u radu, odnosno u komunikaciji s pomoćnikom. Takvi nas primjeri navode na potrebu za kvalitetnom edukacijom koja će, između ostaloga, staviti naglasak na komunikacijske vještine.

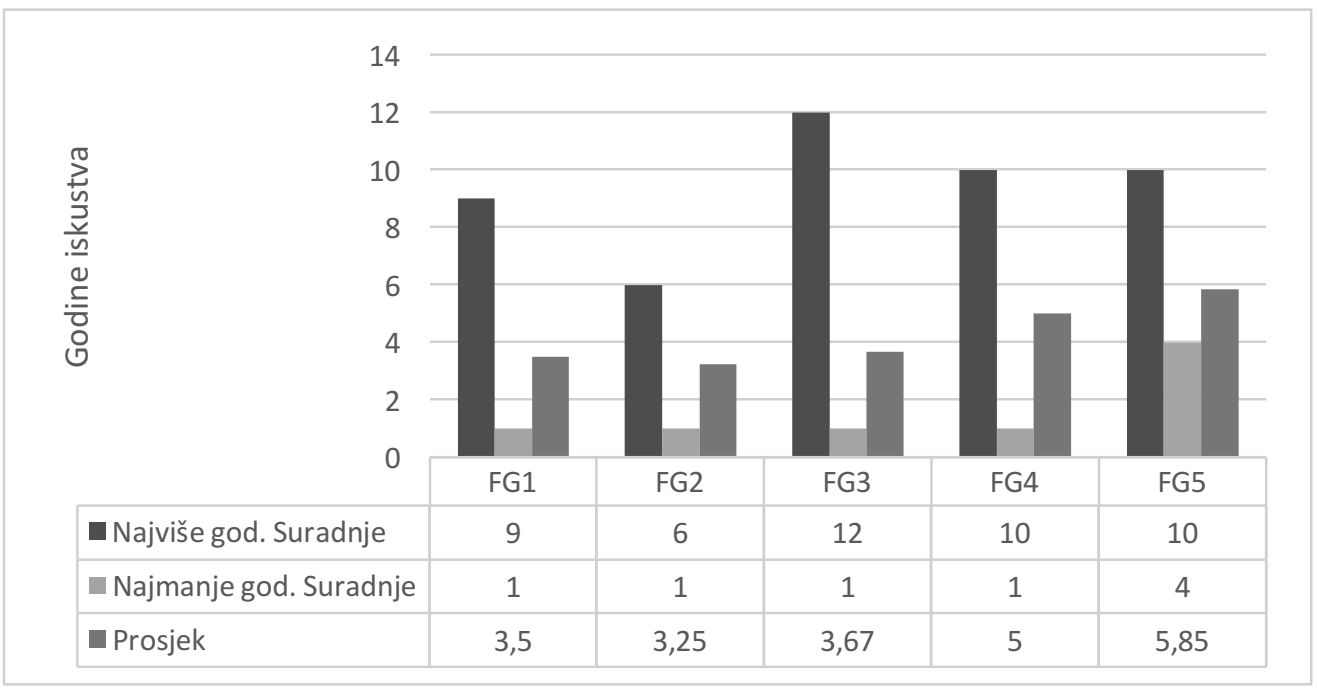

Grafikon 1. Godine iskustva suradnje učitelja s pomoćnikom u nastavi 
Istraživanje je pokazalo kako (3) pomoćnici u nastavi bez odgovarajuće edukacije nisu upoznati sa svim aspektima rada pomoćnika, ne prepoznaju što sve podrazumijeva svakodnevni rad u školi, kao što je primjer pomoćnika u istraživanju koji se trudi biti neprimjetan učitelju i učenicima u razredu. Kvalitetno educirani pomoćnici uključuju se u razrednu zajednicu, pokazuju dobre vještine suradnje s djelatnicima škole, prepoznaju potrebe učenika i aktivno se uključuju u proces poučavanja.

Osim što utjecaj na suradnju ima duljina iskustva te primjerena edukacija pomoćnika, (4) podrška stručne službe škole, odnosno koordinatora za pomoćnike u nastavi, također se pokazala vrlo važnom. Koordinator za pomoćnike ima ulogu medijatora, osobe koja će svakodnevno pratiti rad pomoćnika, isticati područja rada koja iskazuju potrebu za unaprjeđenjem te pratiti učinak suradnje učitelja i pomoćnika. Potrebno je istaknuti navedenuulogu koordinatora kako bi se nastavila unaprjeđivati školska praksa. Svaka škola koja je sudjelovala u istraživanju unutar stručne službe imala je zaduženog koordinatora za pomoćnike u nastavi, no važno je naglasiti podršku edukacijskog rehabilitatora kao koordinatora. Ako u školi ne postoji stručnjak takvog profila, potrebna se podrška može osigurati i u vidu mobilnog stručnog tima koji svojim periodičnim posjetima školi može pružiti potrebnu pomoć.

Ono što je važno, a bez čega učitelj i pomoćnik ne mogu kvalitetno raditi, jest odvojeno vrijeme za planiranje i evaluaciju rada, razmjenu mišljenja i prijedloga za unaprjeđenje. Istraživanje je pokazalo kako se suradnja učitelja i pomoćnika odvija neposredno prije početka sata, kada pomoćnik dobiva upute za rad, a u nekim primjerima ta suradnja započinje tek sredinom sata. Takva praksa ne može proizvesti dobre rezultate rada niti omogućiti učeniku s posebnim edukacijskim potrebama dobro prilagođenu nastavu. Nadalje, komunikacija između učitelja i pomoćnika odvija se tijekom školskog odmora, prije početka sata ili na kraju sata čime suradnja prestaje krajem nastavnog sata odnosno dana. Takva praksa nije učinkovita i ona nas treba usmjeriti prema promjeni pogleda na to što sve podrazumijeva posao učitelja koji surađuje s pomoćnikom. Od velike je važnosti da učitelj i pomoćnik zajedno planiraju nastavni proces te dijele odgovornost u podučavanju, ne samo učenika s posebnim edukacijskim potrebama nego cjelokupnog razreda. Pri tome je važno voditi računa da je učitelj taj koji je zadužen za nastavni plan i program, a pomoćnik ima ulogu izvršavanja zadataka koje mu učitelj dodijeli. Učitelj je moderator koji potiče i usmjerava rad pomoćnika s manjom grupom učenika ili sa svim učenicima u razredu. Stoga je važno naglasiti kako je provedeno istraživanje pokazalo da se u hrvatskim školama u središtu suradnje učitelja i pomoćnika još uvijek nalazi učenik s teškoćama a ne razredna zajednica. Podrška se pruža isključivo njemu, a ne grupi učenika različitih sposobnosti i vještina.

Na temelju dobivenih rezultata istraživanja i njihove analize možemo predstaviti preporuke za dobar razvoj suradnje učitelja i pomoćnika u nastavi:

1. Sustav koji prepoznaje pomoćnika u nastavi kao educiranog odgojno-obrazovnog djelatnika s kompetencijama i znanjima potrebnima za kvalitetno pružanje podrške učeniku s posebnim edukacijskim potrebama i satnicom koja predviđa pripremu i suradnju s učiteljima kako bi se omogućila što bolja podrška. Edukacija pomoćnika u nastavi mora sadržavati znanja s područja edukacijske inkluzije i vještine suradnje s ostalim djelatnicima odgojno-obrazovne ustanove temeljena na suvremenim istraživanjima i primjerima dobrih praksi iz zemalja koje imaju tradiciju uvođenja pomoćnika u nastavi u redovni sustav obrazovanja.

2. Propisani načini suradnje učitelja i pomoćnika koji usmjeravaju pozornost na osiguravanje dovoljnog vremena za planiranje rada učitelja i pomoćnika kao i evaluaciju učinkovitosti timskog rada i provedenih aktivnosti. Planiranje rada podrazumijeva: razradu aktivnosti i zadataka te jasno postavljanje njihovih ciljeva, prilagodbe sadržaja i metode rada, planiranje podrške učeniku s posebnim edukacijskim potrebama, ali i svim drugim 
Mateja Marinić, Klara Matejčić, Ljiljana Igrić KVALITETA SURADNJE UČITELA I POMOĆNIKA U NASTAVI IZ...

učenicima, planiranje podrške tijekom provjere znanja, način praćenja i evidentiranja mogućih poteškoća tijekom usvajanja nastavnog gradiva, planiranje postupnog smanjivanja pružanja podrške pomoćnika s ciljem povećanja samostalnosti učenika i njegovog uključivanja u razrednu zajednicu. Učitelj i pomoćnik stoga moraju biti upoznati s onime što se očekuje od njihovog zajedničkog rada.

3. Aktivno uključenje koordinatora za pomoćnike u nastavi u rad učitelja i pomoćnika. Pružanje podrške njihovoj suradnji na temelju specifičnih znanja koordinatora o razvojnim posebnostima učenika s pojedinim teškoćama, primjerenim oblicima podrške i prilagodbe nastavnog procesa. Uloga edukacijskog rehabilitatora u provedenom se istraživanju pokazala kao važnom podrškom s obzirom na to da ima potrebna znanja iz područja edukacijske inkluzije te prilagodbe nastavnog sadržaja i metoda rada prema razvojnim posebnostima učenika.

4. Proširiti u praksi suradnju - podršku učitelja i pomoćnika na grupu učenika i/ili cijeli razred.Planiranje zadataka i realiziranje aktivnosti koje će staviti naglasak na grupu učenika i aktivnost pomoćnika usmjerenu prema njima. Pomoćnik je u nastavi djelatnik koji svoju podršku može pružati svakom učeniku u razredu neovisno o teškoćama. lako će učenik s posebnim edukacijskim potrebama zahtijevati veći opseg podrške tijekom nastavnog sata ili dana ovisno o svojim potrebama, važno je neposredni rad pomoćnika preusmjeriti prema razrednoj zajednici. Svakodnevni rad uključuje usmjeravanje pozornosti i praćenje rješavanje zadataka, poticanje grupne aktivnosti ili rada u paru, provjeravanje razumijevanja dobivenih uputa koje je učitelj zadao učeniku. Pomoćnik u nastavi dio svog radnog dana uvijek može usmjeriti prema pružanju podrške učenicima koji dobro prate i uredno svladavaju nastavni program kako bi učitelj svoju pozornost usmjerio prema učeniku s posebnim edukacijskim potrebama, provjerio njegovo razumijevanje sadržaja, podučio novim pojmovima ili vještinama. Pomoćnik u nastavi ne može biti zamjena za učitelja.

5. Jasno definirana uloga učitelja i pomoćnika unutar razrednog odjela odnosno škole. Kada postoji potpuno razumijevanje uloge učitelja i uloge pomoćnika, onda možemo govoriti o uspješnoj suradnji koja proizvodi dobre rezultate. Kako bi ih učitelj i pomoćnik u potpunosti bili svjesni, važno je oba djelatnika educirati čime će se posljedično razbiti predrasude ili zablude o radu pomoćnika (primjerice: pomoćnik u nastavi dužan je sjediti pored učenika s posebnim edukacijskim potrebama tijekom cijelog nastavnog sata i/ili dana, ako učenika s posebnim edukacijskim potrebama nema na nastavi, tada ni pomoćnik nije dužan biti nazočan, ako učenik s posebnim edukacijskim potrebama određenu aktivnost može izvoditi samostalno, pomoćnik nije potreban na satu).

\section{ZAKUUČAK}

U skladu s postavljenim istraživačkim pitanjem koje se odnosi na suradnju učitelja i pomoćnika možemo reći da je ona u praksi raznolika i specifična za pojedinu školu. Koliko će biti dobra i time usmjerena na pružanje podrške cijeloj razrednoj zajednici, ovisi o pojedinačnom primjeru, odnosno dodatnom angažmanu učitelja i pomoćnika. Pojedini aspekti kvalitete suradnje podudaraju se među grupama učitelja i pomoćnika, ali ono u čemu se grupe djelomično slažu jest vrijeme suradnje, zajednički poslovi i podrška učitelja pomoćniku. Suradnja nije regulirana niti se u školama prepoznaje što ju zapravo čini, odnosno da se ona temelji na suradničkom poučavanju. Kako to ne bi bio slučaj, potrebno je usklađivanje rada učitelja i pomoćnika unutar razredne zajednice. Učitelji i pomoćnici u nastavi međusobnu suradnju opisuju kao korektnu, no postoje prepreke u komunikaciji zbog čega obje strane teže komuniciranju pa je te aspekte rada potrebno izmijeniti i poboljšati. Suradnja učitelja i pomoćnika uglavnom se odvija neposredno prije početka nastavnog sata kada pomoćnik na licu mjesta dobiva upute za 
rad i uvodi ga se u nastavni sadržaj.Učitelji najveću podršku od pomoćnika očekuju u usmjeravanju učenika i regulaciji njegovog ponašanja tijekom nastave. Učitelj i pomoćnik surađuju u pripremi ispita znanja i prilagodbi nastavnog sadržaja i metoda rada gdje učitelj priprema aktivnosti i zadatke, a pomoćnik dobiva upute kako ih provesti, no to nije slučaj u svim fokus grupama s obzirom na situacije gdje pomoćnik sam priprema ispite i prilagođava nastavni sadržaj. Pomoćnici u nastavi i učitelji predmetne nastave teže pronalaze vrijeme za suradnju s obzirom na to kako je predmetna nastava organizirana. Učitelji prepoznaju podršku pomoćnika, no postoji tendencija da pomoćnici preuzimaju veću odgovornost u prilagodbi sadržaja i poučavanju učenika s posebnim edukacijskim potrebama, a učitelji se isključivo posvećuju poučavanju ostatka razreda zbog čega svatko od njih djeluje za sebe što dovodi do izoliranja učenika s teškoćama i pomoćnika od razredne zajednice.

\section{LITERATURA}

Arguelles, M. E., Hughes, M. T. i Schumm, J. S. (2000). Co-teaching: A different approach to inclusion. Principal, 79(4), 50-51.

Grant, M. (2014). A Tale of Two Teachers: An Analytical Look at the Co-Teaching Theory Using a Case Study Model. Preuzeto s https://files.eric.ed.gov/fulltext/ED563448.pdf, 20.5.2019.

Igrić, Lj. (2015). Osnove edukacijskog uključivanja. Zagreb: Školska knjiga.

Igrić, Lj., Wagner Jakab, A. i Cvitković, D. (2009). Djeca s teškoćama učenja u interaktivnom sustavu obitelj-škola-vršnjaci. Hrvatska revija za rehabilitacijska istraživanja, 45(1), 31-38.

Mejovšek, M. (2008). Metode znanstvenog istraživanja u društvenim i humanističkim znanostima. Jastrebarsko: Naklada Slap.

NJEA (2012). Co-teaching: Strategies for successful collaboration. Preuzeto s http://m.njea.org/ news-and-publications/njea-review/march-2012/co-teaching-strategies for-successfulcollaboration. 20.2.2019.

Pope, C, Ziebland, S. i Mays, N. (2000). Qualitative research in health care Analysing qualitative date. $B M J$ 320, 114, doi:10.1136/bmj.320.7227.114. 15.1.2019.

Ritchie, J. i Spencer, L. (1994). Qualitative data analysis for applied policy research. U: Bryman i R. G. Burgess (ur.). Analysing qualitative data (str. 173-194). London: Rutledge.

Sharpe, M.N. i Hawes, M.E. (2003). Collaboration between general and special education: Making it work. National Center on Secondary Education and Transition Issue Brief, 2(1), 1-5.

Vaughn, S. i Schumm, J.S. (1995). Responsible Inclusion for Students with Learning Disabilities. Journal of Learning Disabilities, 28(5), 264-270.

Vincett, K., Cremin, H. i Thomas, G. (2005). Teachers and Assistants Working Together. Berkshire: Open University press.

\section{The Quality of Teacher and Teaching Assistant Collaboration from a Teacher and Teaching Assistant Perspective}

\footnotetext{
Abstract: For the class to be a supportive community in the learning process, it requires a high level of co-operation between teachers and teaching assistants. It is particularly emphasized that those teachers who are supported by teaching assistants feel greater satisfaction in everyday work than those in whom such support is lacking. The presented research is based on research questions seeking to gain insight into the perception of teachers and teaching assistants on the ways of their cooperation as well as which factors contribute to the quality of cooperation. The conducted research included classroom and subject teachers $(N=40)$ and teaching assistants $(N=29)$ from 7 elementary schools in Croatia. The data was collected by focus group interviews and analyzed and processed by qualitative data analysis. The results
} 
Mateja Marinić, Klara Matejčić, Ljiljana Igrić KVALITETA SURADNJE UČITELJA I POMOĆNIKA U NASTAVI IZ.

point to specific areas of cooperation between teachers and teaching assistants. Since the teaching assistants are the ones who spend the most time in direct work with the student, the teachers see them as an associate who knows the pupil well, his abilities and characteristics. Therefore, we can conclude that the teaching assistant has an indispensable role in inclusion of students with special educational needs.

Keywords: inclusive education, teacher, teaching assistant, collaborative teaching, qualitative research

\section{Qualität der Zusammenarbeit und von Lehrern und Unterrichtshelfern aus der jeweiligen perspektive}

Zusammenfassung: Damit die Klasse zu einer unterstützenden Gemeinschaft im Lernprozess wird, ist es wichtig, dass eine gute Zusammenarbeit im Unterricht zwischen Lehrern und Unterrichtshelfern besteht. Es wird besonders betont, dass jene Lehrer, die eine Unterstützung vom Unterrichtshelfer im Unterricht bekommen eine größere Lust bei der alltäglichen Arbeit verspüren im Unterschied zu denjenigen Lehrern, die eine solche Unterstützung nicht bekommen. In der dargestellten Untersuchung versucht man durch Untersuchungsfragen eine Einsicht in die Perzeption des Lehrers und Unterrichtshelfers zu gewinnen, was die Art und Weise ihrer Zusammenarbeit betrifft. Ebenfalls möchte man erfahren, welche Faktoren zu einer guten Zusammenarbeit beitragen. Die durchgeführte Untersuchung erfasste Grundschullehrer (1.-4. Klasse) und Lehrer, die ein bestimmtes Fach unterrichten (N-40) sowie Unterrichtshelfer $(\mathrm{N}=29)$ aus $7 \mathrm{Grundschulen} \mathrm{in} \mathrm{Kroatien.} \mathrm{Die} \mathrm{Daten} \mathrm{wurden} \mathrm{mithilfe} \mathrm{von} \mathrm{Fokusgruppeninterviews} \mathrm{erhoben,}$ analysiert und mittels qualitativer Datenanalyse bearbeitet. Die Ergebnisse weisen auf spezifische Gebiete der Zusammenarbiet zwischen Lehrern und Unterrichtshelfern hin. Da die Unterrichtshelfer die meiste Zeit in unmittelbarer Zusammenarbeit mit den Schülern verbringen, sehen die Lehrer in ihnen Mitarbeiter, die die Schüler, ihre Fähigkeiten und ihr Wesen kennen. Nach dieser Untersuchung können wir schlussfolgern, dass der Unterrichtshelfer eine sehr wichtige Rolle bei der Einbeziehung von Schülern mit besonderen Erziehungs- und Bildungsbedürfnissendes spielt.

Schlüsselwörter: inklusive Bildung, Lehrer, Unterrichtshelfer, kooperatives Unterrichten, qualitative Untersuchung 